\title{
Investigation of Genetics Divergence in Newly Developed Local Sunflower (Helianthus annuus L.) Hybrids
}

\author{
Muhammad Arshad*, Sabeeta Jan, Sundas Awan, Samra Azam, Shiguftah Khalid and Muahmmad Ayub \\ Khan
}

Oilseeds Programme, Crop Sciences Institute, National Agricultural Research Centre, Park Road, Islamabad, Pakistan.

Abstract | Locally developed twenty four sunflower hybrids were appraised for different agronomic traits to assess genetic specifications, genetic divergence, and correlation coefficient, direct and indirect effects of eight characters towards seed yield under field condition. Experiment was conducted according to RCBD design at NARC (National Agricultural Research Centre), Islamabad during year 2015. Data were recorded on Days to flower initiation, Days to flower completion and Days to maturity, 100 seed weight, oil content percentage and Seed Yield. Results of ANOVA revealed that there is remarked variation among all hybrids under study for seed yield and other allied character while non-significant differences were observed for replications except days to flower initiation. In the present study both positive and negative correlations were found between different traits. Days to flower initiation (DFI), days to flower completion (DFC) and days to maturity (DM) contribute positively and highly significantly with plant height $(\mathrm{PH})$ for both genotypic and phenotypic level. Correlation between plant height and oil content was found to be highly significant and positive. Seed yield had positive association but non-significant with DFI, PH 100SW, HD and OC percentage while negative association with DFC and DM. DFI, DFC, HD, 100 SW and OC percentage contribute positively toward seed yield. Present study depicts that for improvement in yield, HD and oil content should be given top priority. Based on WARD's method genotypes were assigned into seven clusters at $25 \%$ linkage distance. Hybrids in Cluster II and IV with high seed yield and oil content were selected as desirable hybrids and suggested to exploit further under diverse environments.

Received | August 30, 2017; Accepted | September 28, 2018; Published | December 13, 2018

*Correspondence | Muhammad Arshad, Oilseeds Programme, Crop Sciences Institute, National Agricultural Research Centre, Park Road, Islamabad, Pakistan; Email: marshadnarc@hotmail.com

Citation | Arshad, M., S. Jan, S. Awan, S. Azam, S. Khalid and M.A. Khan. 2019. Investigation of genetics divergence in newly developed local sunflower (Helianthus annuus L.) hybrids. Pakistan Journal of Agricultural Research, 32(1): 33-40.

DOI | http://dx.doi.org/10.17582/journal.pjar/2019/32.1.33.40

Keywords | Sunflower, Helianthus annuus L., Correlation Coefficient, Path Analysis, Cluster analysis

\section{Introduction}

Sunflower botanically known as Helianthus annuus LL. is an imperative crop mainly grown for production of oil however also used as raw material in industry (Mijic et al., 2009). Sunflower ranked third among major oil producing crops (cotton, brassica and sunflower) in Pakistan. Area of sunflower during 2016-17 (Spring) was 216 (000 Acres) having oil production of 41000 tons (Economic Survey of Pakistan, 2016-17).
Sunflower seeds contain 50\% Fat and 20\% protein. Sunflower oil is of finest quality oil because of increased percentage of unsaturated fatty acids, light color, low quantity of linolenic acid, blend flavor and high smoke point. Oleic and linoleic acid are primary fatty acids (approximately $90 \%$ unsaturated fatty acids) in sunflower oil, however among others are palmitic and stearic saturated fatty acids (Arshad et al., 2007). In Pakistan, sunflower is a second major source 
of vegetable oil after cottonseed (Arshad et al., 2010). It was cultivated on an area of 152693 hectares with the production of 193122 tons with an average seed yield of $1265 \mathrm{~kg} / \mathrm{ha}$ (Figure 1). Sunflower contributes to 41 thousand tons of edible oil and $22 \%$ of the local oil production Economic Survey of Pakistan, (2016-17).

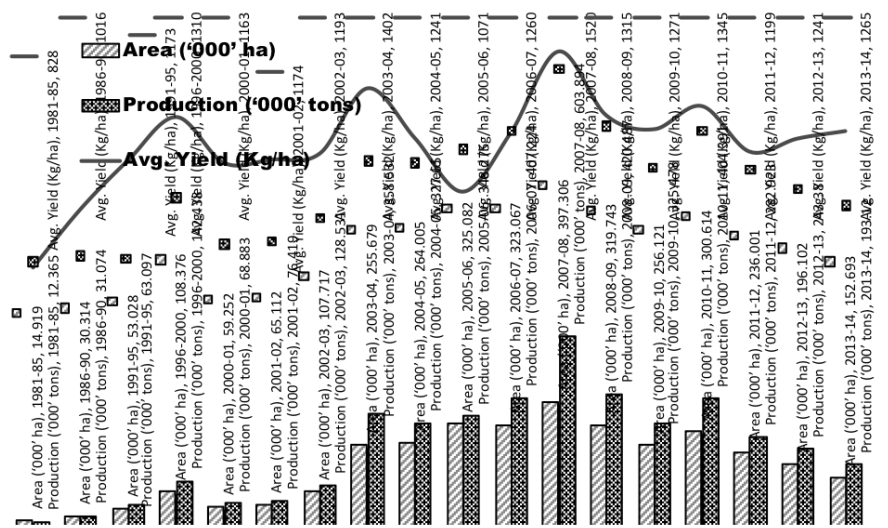

Figure 1: Area, production and seed yield of sunflower in Pakistan since 1981. First four bars are representing five years data and remaining are annual data.

During early 1990's sunflower was introduced in Pakistan as oil crop but up to 2003 area lingered however afterwards it increased rapidly. The maximum area (397300 ha) and production (603300 tons) was reported in year 2007-08. Thereafter it has been decreasing gradually (Figure 1). Pakistan is facing acute shortage of edible oil due to increased demand and lower domestic production. Sunflower is the most appropriate source of edible oil in Pakistan. It is short duration, drought tolerant and high seed yielding crop.

In sunflower breeding for high yield, it is necessary to find the morphological and physiological traits, which can be easily improved and have strong correlation with seed yield and oil content, as selection criteria (Škorić et al., 2002). In sunflower, seed yield is a quantitative trait and dependent on its component's characters (Arshad et al., 2007). Correlation between seed yield and yield components help us to select desirable cultivar. The analysis of indices separate direct effect of each trait from indirect effect on seed yields (Bidgoli et al., 2006).

In previous studies on sunflower, path coefficient analysis was used to partition direct effect of genotypic correlation from indirect effect. Likewise, researchers (Arshad et al., 2004 and 2006; Ghafoor and Ahmad, 2005) used similar approach to quantify different agronomic traits. Therefore, current study was designed to evaluate the correlation among different yield traits both at genotypic and phenotypic level and path coefficient analysis for measurement of direct and indirect effects of various traits on seed yield in sunflower.

\section{Materials and Methods}

The material consisted of twenty-two local hybrids and two exotic hybrids (Hysun-33 and Nk-S-278) were included as checks for comparison. RCBD is used as layout for experiment along with three replications in Spring 2016 at NARC (National Agricultural Research Centre), Islamabad, Pakistan. Each hybrid was sown in four rows of five-meter length while $\mathrm{R}-\mathrm{R}$ and $\mathrm{P}-\mathrm{P}$ spacing were kept at 75 and $25 \mathrm{~cm}$ respectively. Ridge sowing was done by dibbler having 2-3 seeds per hill up to the depth of 2-3 cm for maintaining plant density. Recommended agronomic practices were followed during whole crop season to attain healthy crop stand. Fertilizers were applied @ $120 \mathrm{~kg} / \mathrm{ha}$ nitrogen and $60 \mathrm{~kg} / \mathrm{ha}$ phosphorus and 60 $\mathrm{kg} / \mathrm{ha}$ potassium were applied to exploit the potential yield of hybrids. Thinning was done to obtain optimum plant population. Ten plants were indiscriminately selected to record data at flowering stage. Data were recorded on Days to Flower Initiation (DFI), Days to Flower Completion (DFC), Days to Maturity (DM), Plant Height $(\mathrm{PH} \mathrm{cm})$, Head Diameter $(\mathrm{HD} \mathrm{cm})$, Seed Yield $\left(\mathrm{SY} \mathrm{Kg} / \mathrm{ha}^{-1}\right)$ after harvest and at $8 \%$ seed moisture, 100SW (g) and OC \%. The oil content of the oven-dried seeds was determined by nuclear magnetic resonance (NMR).

Singh and Chaudhary (1979) suggested method to compute genetic characters and correlation analysis (phenotypic, genotypic and environmental). The analysis in present study followed techniques of Singh and Chaudhary (1979). However, other scientists like Reeve and Rao (1981) suggested method to evaluate genotypic correlation by using standard error. Dewey and $\mathrm{Lu}$ (1973) recommended procedure for analysis of path coefficient. Cluster diagram was constructed by following WARD's method proposed by Sneath and Sokal, (1973).

\section{Results and Discussion}

\section{Mean values and analysis of variance}

The mean values and range of seed yield and other agronomic traits of twenty four sunflower hybrids during the period of study are presented in Table $1 . \mathrm{Av}$ erage values of days to flower initiation ranged from 
Table 1: Characters means and ranges of yield and its related components in 24 bybrid sunflower.

$\begin{array}{llllllllll}\text { S. No. } & \text { Hybrids } & \text { DFI } & \text { DFC } & \text { DM } & \text { PH } & \text { HD } & \text { SY }\left(\mathbf{K g} / \mathbf{h a}^{-\mathbf{1}}\right) & \mathbf{1 0 0 ~ S W} & \text { OC\% } \\ \mathbf{1} & \text { Hysun-33 } & 90 & 96 & 129 & 238 & 18.6 & 3295 & 6.42 & 38.1 \\ \mathbf{2} & \text { NK-S-278 } & 88 & 92 & 125 & 210 & 18.2 & 3417 & 5.93 & 41.7 \\ \mathbf{3} & \text { SMH-0821 } & 82 & 90 & 123 & 187 & 18.3 & 3219 & 7.06 & 38.4 \\ \mathbf{4} & \text { SMH-0907 } & 84 & 93 & 126 & 186 & 19.7 & 3283 & 6.30 & 37.8 \\ \mathbf{5} & \text { SMH-0909 } & 83 & 90 & 123 & 209 & 17.3 & 3166 & 5.56 & 38.2 \\ \mathbf{6} & \text { SMH-0917 } & 82 & 92 & 125 & 205 & 16.9 & 3327 & 5.17 & 37.9 \\ \mathbf{7} & \text { SMH-0925 } & 89 & 95 & 128 & 268 & 19.2 & 2767 & 5.95 & 41.4 \\ \mathbf{8} & \text { SMH-0926 } & 85 & 94 & 127 & 212 & 21.1 & 3007 & 5.99 & 37.2 \\ \mathbf{9} & \text { SMH-0927 } & 88 & 95 & 128 & 225 & 17.3 & 3324 & 4.76 & 38.5 \\ \mathbf{1 0} & \text { SMH-0932 } & 84 & 91 & 124 & 174 & 19.1 & 2713 & 5.21 & 38.0 \\ \mathbf{1 1} & \text { SMH-1001 } & 84 & 93 & 126 & 216 & 16.3 & 2788 & 5.69 & 39.2 \\ \mathbf{1 2} & \text { SMH-1006 } & 82 & 90 & 123 & 190 & 17.7 & 3031 & 6.36 & 36.0 \\ \mathbf{1 3} & \text { SMH-1023 } & 84 & 91 & 124 & 222 & 18.2 & 3072 & 7.04 & 38.4 \\ \mathbf{1 4} & \text { SMH-1026 } & 81 & 90 & 123 & 163 & 18.6 & 2762 & 5.50 & 36.8 \\ \mathbf{1 5} & \text { SMH-1027 } & 78 & 89 & 122 & 158 & 17.5 & 2938 & 5.41 & 39.1 \\ \mathbf{1 6} & \text { SMH-1028 } & 80 & 89 & 122 & 174 & 18.7 & 3144 & 6.51 & 36.9 \\ \mathbf{1 7} & \text { SMH-1104 } & 83 & 94 & 127 & 203 & 19.2 & 2428 & 6.02 & 38.3 \\ \mathbf{1 8} & \text { SMH-1206 } & 81 & 91 & 124 & 211 & 17.7 & 3057 & 7.65 & 39.2 \\ \mathbf{1 9} & \text { SMH-1208 } & 82 & 89 & 122 & 208 & 16.8 & 3346 & 6.41 & 39.0 \\ \mathbf{2 0} & \text { SMH-1215 } & 85 & 94 & 127 & 225 & 16.2 & 3359 & 6.57 & 37.9 \\ \mathbf{2 1} & \text { SMH-1221 } & 81 & 91 & 124 & 202 & 19.2 & 3764 & 6.23 & 37.5 \\ \mathbf{2 2} & \text { SMH-1301 } & 79 & 89 & 122 & 203 & 19.1 & 3400 & 6.74 & 39.7 \\ \mathbf{2 3} & \text { SMH-1302 } & 82 & 95 & 128 & 200 & 23.6 & 2567 & 6.80 & 38.0 \\ \mathbf{2 4} & \text { SMH-1401 } & 81 & 90 & 123 & 224 & 19.1 & 3353 & 6.02 & 40.8 \\ & \text { Character Mean } & 83 & 92 & 125 & 205 & 18.5 & 3105 & 6.14 & 38.5 \\ & \text { Character Range } & 78-90 & 89-96 & 122-129 & 158-268 & 16.2-23.6 & 2428-3764 & 4.76-7.65 & 36-41.7\end{array}$

DFI: Days to flower initiation; DFC: Days to flower completion; DM: Days to Maturity; PH: Plant height (cm); HD: Head diameter (cm); SY: Seed yield (Kg ha-1); 100SW; 100 Seed weight (g); OC\%: Oil content \%

78-90 days with average value of 83 days in sunflower hybrids. The maximum value for days to flower initiation was observed in Hysun-33. Similarly, the days to flower completion and maturity ranged from 8996 and 122 to 129 , respectively. The maximum days were also taken by Hysun-33 to mature while minimum 122 days were recorded in three different hybrids (SMH-1027, SMH-1028 and SMH-1208). Maximum Plant height $(268 \mathrm{~cm})$ was recorded in hybrid SMH- 0925 and minimum in SMH-1027 $(158 \mathrm{~cm})$. Mean value of head diameter was observed $18.5 \mathrm{~cm}$ with minimum value of $16.2 \mathrm{~cm}$ in SMH-1215 and maximum $23.6 \mathrm{~cm}$ in SMH-1302. Hundred seed weight is also an important trait in determining the sunflower yield. Hundred seed weight in this study ranged from 4.76 to $7.65 \mathrm{~g}$ with an average of $6.14 \mathrm{~g}$. Similar results had been documented by Arshad et al. (2007) who reported the minimum and maximum value for this trait were 4.57 and $7.13 \mathrm{~g}$, respectively. Oil content in sunflower hybrids depend on genetic potential as well as environmental conditions (Haldni et al., 2006). The average value for oil content was $38.5 \%$. The highest percentage of oil was determined in NK-S-278 (41.7\%) and the lowest (36.0\%) in SMH- 1006 (36.0\%). The highest seed yield was $\left(3764 \mathrm{Kg} \mathrm{ha}^{-1}\right.$ ) was recorded in SMH-1221 and minimum $2428 \mathrm{Kg} \mathrm{ha}^{-1}$ in SMH-1104. An average yield of $3105 \mathrm{Kg} \mathrm{ha}^{-1}$ was observed in this experiment. Lower value of an average seed yield of $2160 \mathrm{Kg} \mathrm{ha}{ }^{-1}$ was outlined by Kaya et al. (2009) whereas Mijic et al. (2009) reported higher values for seed yield $4215 \mathrm{Kg}$ ha ${ }^{-1}$ in sunflower hybrids as compared to results in current study where highest seed yield of $3764 \mathrm{Kg}$ $\mathrm{ha}^{-1}$ was reported in SMH-1221 and lowest seed yield of $2428 \mathrm{~kg} \mathrm{ha}^{-1}$ by SMH-11024. 
Table 2: Analysis of variance for yield and its related components in 24 bybrid sunflower.

$\begin{array}{lllllllll}\text { Variable } & \text { DFI } & \text { DFC } & \text { DM } & \text { PH } & \text { HD } & \text { SY }\left(\mathbf{K g ~ h a}^{-1}\right) & \mathbf{1 0 0 ~ S W ~} & \text { OC \% } \\ \text { MS (Var) } & 28.23^{* *} & 16.03^{* *} & 16.03^{* * *} & 1764.86^{* *} & 7.50^{* *} & 295482.40^{* * *} & 1.39^{\text {*** }} & 5.69^{* * *} \\ \text { MS (Rep) } & 4.04^{*} & 1.94^{\text {ns }} & 1.90^{\text {ns }} & 767.75^{\text {ns }} & 3.22^{\text {ns }} & 14410.67^{\text {ns }} & 0.63^{\text {ns }} & 1.32^{\text {ns }} \\ \text { MS (E) } & 1.013 & 1.96 & 1.97 & 673.50 & 1.09 & 8391.88 & 0.36 & 1.52 \\ \text { F. Ratio (V) } & 27.87 & 8.18 & 8.17 & 2.62 & 6.92 & 35.21 & 3.83 & 3.75 \\ \text { F. Ratio (R) } & 3.99 & 0.99 & 0.97 & 1.14 & 2.97 & 1.72 & 1.72 & 0.87 \\ \text { Standard error } & 0.58 & 0.81 & 0.81 & 14.98 & 0.60 & 52.89 & 0.35 & 9.71 \\ \text { CD1 } & 1.64 & 2.29 & 2.29 & 42.38 & 1.70 & 149.59 & 0.98 & 2.01 \\ \text { CD2 } & 2.19 & 3.04 & 3.04 & 56.37 & 2.26 & 198.96 & 1.31 & 2.67 \\ \text { Genotypic Variance } & 9.07 & 4.69 & 4.69 & 363.79 & 2.14 & 95696.85 & 0.34 & 1.39 \\ \text { Phenotypic Variance } & 10.08 & 6.65 & 6.65 & 1037.29 & 3.22 & 104088.70 & 0.70 & 2.91 \\ \text { GCOV } & 3.62 & 2.36 & 1.73 & 9.32 & 7.91 & 9.96 & 9.52 & 3.06 \\ \text { PCOV } & 3.82 & 2.81 & 2.07 & 15.73 & 9.71 & 10.39 & 13.66 & 4.43 \\ \text { COH } & 0.90 & 0.71 & 0.71 & 0.35 & 0.66 & 0.92 & 0.49 & 0.48\end{array}$

Analysis of variance revealed significant differences among all hybrids for seed yield and other related traits while non significant differences for replications except days to flower initiation indicating lesser effect of environment (Table 2). In sunflower hybrids, correlation and variability of grain yield with different characters was reported by Abbas et al. (2014). They reported tremendously significant differences among all hybrids for all morphological traits except for oil content. Khan (2001) found highly significant difference among ten yield contributing characters of sunflower studied at $5 \%$ probability level.

\section{Correlation coefficient}

Genotypic, phenotypic and environmental correlation coefficients were computed for seed yield and related traits studied (Table 3). Phenotypic correlation was inferior in most traits than genotypic coefficient stipulating that association between traits is influenced genetically. Jockovic et al. (2015) evaluated fifty new sunflower hybrids and found that phenotypic correlation was generally lesser than genotypic correlation showing that inherent association of traits combinations were greater than environmental effects (Anwar-ul-Haq et al., 2005).

Correlation coefficient determines the closeness of two important variables so that selection criteria could be reliably established. In the present study both positive and negative correlations were found between different traits. The analysis of correlation coefficients showed that days to flower initiation, completion and days to maturity effects positively and highly significantly with plant height for both genotypic and phe- notypic levels in sunflower hybrids under study. Plant height was highly significant and positively correlated with oil content $\left(0.785^{* * *}\right)$. The results are similar to early findings of Arshad et al. (2010) who found that DFI, DFC and DM had positive correlation with plant height. Similar results were reported by Zia et al. (2013) and Farhatullah et al. (2006) who found that long heighted plants had secured higher percentage of oil content in contrast to short heighted. Taller plants able to produce greater harvest index that result in higher seed weight and in turn yield high oil content. Furthermore, Plant height, 1000 seed weight and head diameter were found positively and significantly correlated with sunflower yield was also reported. Seed yield/plant had significant and positive association with plant height and hundred seed weight reported by Dasgustu, (2002). In contrary to results in this study, Machikowa and Chiraporn (2008) found highly significant correlation coefficients (0.641 and 0.551) of seed yield with head diameter and plant height respectively. Positive correlation but non-significant $(0.154)$ was observed between seed yield and oil content. Oil content showed non-significant and negative phenotypic correlation $(-0.158)$ with hundred seed weight.

\section{Path coefficient analysis}

The path coefficient analysis is used to know the magnitude of effects of independent variables on dependent ones. Therefore, genotypic correlation was partitioned into both direct as well as indirect effects of individual characters on seed yield $\left(\mathrm{Kg} \mathrm{ha}^{-1}\right)$. Cumulative effects of seven traits on seed yield are given in Table 4. Days to flower initiation (1.08), days to flower 
Table 3: Genotypic $(r G)$, phenotypic $(r P)$ and environmental $(r E)$ correlation coefficients among 7 characters in 24 sunflower bybrids.

\begin{tabular}{|c|c|c|c|c|c|c|c|c|}
\hline Variables & & DFI & DFC & DM & PH & HD & SY $\left(\mathrm{Kg} \mathrm{ha}^{-1}\right)$ & $100 \mathrm{SW}$ \\
\hline \multirow[t]{3}{*}{ DFC } & $\mathrm{rG}$ & $0.843^{* *}$ & 1 & & & & & \\
\hline & $\mathrm{rP}$ & $0.721 * *$ & 1 & & & & & \\
\hline & $\mathrm{rE}$ & 0.290 & 1 & & & & & \\
\hline \multirow[t]{3}{*}{ DM } & $\mathrm{rG}$ & $0.843^{* *}$ & $1.000^{* *}$ & 1 & & & & \\
\hline & $\mathrm{rP}$ & $0.721^{* *}$ & $1.000^{* *}$ & 1 & & & & \\
\hline & $\mathrm{rE}$ & 0.290 & $1.000^{* *}$ & 1 & & & & \\
\hline \multirow[t]{3}{*}{$\mathrm{PH}$} & $\mathrm{rG}$ & $0.826^{* *}$ & $0.697^{* *}$ & $0.697^{* *}$ & 1 & & & \\
\hline & $\mathrm{rP}$ & $0.523^{* *}$ & $0.487^{*}$ & $0.487^{*}$ & 1 & & & \\
\hline & $\mathrm{rE}$ & 0.231 & 0.321 & 0.321 & 1 & & & \\
\hline \multirow[t]{3}{*}{ HD } & $\mathrm{rG}$ & -0.020 & 0.327 & 0.327 & -0.033 & 1 & & \\
\hline & $\mathrm{rP}$ & -0.036 & 0.248 & 0.248 & -0.102 & 1 & & \\
\hline & $\mathrm{rE}$ & -0.114 & 0.079 & 0.079 & -0.185 & 1 & & \\
\hline \multirow[t]{3}{*}{$\mathrm{SY}(\mathrm{Kg} / \mathrm{ha})$} & $\mathrm{rG}$ & 0.014 & -0.259 & -0.259 & 0.187 & 0.367 & 1 & \\
\hline & $\mathrm{rP}$ & 0.015 & -0.202 & -0.202 & 0.119 & 0.288 & 1 & \\
\hline & $\mathrm{rE}$ & 0.020 & 0.041 & 0.042 & 0.053 & -0.003 & 1 & \\
\hline \multirow[t]{3}{*}{$100 \mathrm{SW}$} & $\mathrm{rG}$ & -0.213 & -0.190 & -0.190 & 0.182 & 0.211 & 0.114 & 1 \\
\hline & $\mathrm{rP}$ & -0.191 & -0.163 & -0.163 & 0.062 & 0.199 & 0.091 & 1 \\
\hline & $\mathrm{rE}$ & -0.223 & -0.135 & -0.135 & -0.022 & 0.190 & 0.071 & 1 \\
\hline \multirow[t]{3}{*}{ OC\% } & $\mathrm{rG}$ & 0.302 & 0.107 & 0.107 & $0.785^{* *}$ & -0.097 & 0.105 & 0.154 \\
\hline & $\mathrm{rP}$ & 0.211 & 0.010 & 0.010 & 0.282 & -0.077 & 0.082 & -0.158 \\
\hline & $\mathrm{rE}$ & 0.055 & -0.133 & -0.131 & -0.068 & -0.053 & 0.061 & $-0.447^{*}$ \\
\hline
\end{tabular}

Table 4: Direct (bighlighted) and indirect effects of seven traits on seed yield in sunflower.

$\begin{array}{lllllllll}\text { Variables } & \text { DFI } & \text { DFC } & \text { DM } & \text { PH } & \text { HD } & \mathbf{1 0 0 S W} & \text { OC\% } & \text { SY }\left(\mathbf{K g} / \mathbf{h a}^{-1}\right) \\ \text { DFI } & (1.08) & 0.83 & -0.81 & -1.20 & 0.01 & -0.12 & 0.24 & 0.01 \\ \text { DFC } & 0.91 & (0.98) & -0.97 & -1.01 & -0.15 & -.011 & 0.08 & -.026 \\ \text { DM } & 0.91 & 0.98 & (-0.97) & -1.01 & -0.15 & -.011 & 0.08 & -0.26 \\ \text { PH } & 0.89 & 0.68 & -00.67 & (-1.45) & 0.01 & .011 & 0.62 & 0.19 \\ \text { HD } & -0.02 & 0.32 & -0.32 & 0.05 & (0.44) & 0.12 & -0.08 & 0.37 \\ \text { 100SW } & -0.23 & -0.19 & 0.18 & -0.26 & -0.09 & (0.59) & 0.12 & 0.11 \\ \text { OC\% } & 0.33 & 0.11 & -0.10 & -1.14 & 0.04 & 0.09 & (0.79) & 0.10\end{array}$

completion (0.98), head diameter (0.44), hundred seed weight (0.59) and oil contents (0.19) have direct positive effect on sunflower seed yield. On the other hand, days to maturity (-0.97) and plant height $(-1.45)$ exhibited direct negative effects. Among these characters, days to flower initiation had the highest positive impact on seed yield (1.081) proceed by days to flower completion (0.983). However, contradictory findings reported by Arshad et al. (2010) for all parameters except days to flower initiation and head diameter. Negative direct effect of plant height with seed yield was also described by another study of (Anwar-ul-haq et al., 2005). Head diameter had direct positive effect on seed (0.44). Likewise, hundred seed weight and oil content also had high positive direct effects. Oil content had high direct effect on seed yield documented by (Chikkadaviah et al., 2002). Current findings revealed that $100 \mathrm{SW}$, OC percentage, DFI, DFC and HD can be contemplated as assortment benchmark for direct refinement in seed yield while for indirect improvement, plant height and days to maturity are important traits.

\section{Cluster analysis}

Cluster analysis indicates the degree of genetic diversity. Cluster diagram using WARD's method distributed 
Table 5: Mean and standard deviation of seven clusters for eight variables.

\section{Mean \pm Standard Deviation}

$\begin{array}{llllllll}\text { Variable } & \text { Cluster-I } & \text { Cluster-II } & \text { Cluster-III } & \text { Cluster-IV } & \text { Cluster-V } & \text { Cluster-VI } & \text { Cluster-VII } \\ \text { DFI } & 81.00 \pm 2.24 & 82.00 \pm 1.00 & 81.50 \pm 1.64 & 83.50 \pm 0.71 & 83.67 \pm 1.53 & 88.50 \pm 0.71 & 87.67 \pm 2.52 \\ \text { DFC } & 89.80 \pm 0.84 & 91.00 \pm 1.00 & 90.00 \pm 0.89 & 93.50 \pm 0.71 & 94.00 \pm 1.00 & 93.50 \pm 2.12 & 95.00 \pm 1.00 \\ \text { DM } & 122.80 \pm 0.84 & 124.00 \pm 1.00 & 123.00 \pm 0.89 & 126.50 \pm 0.71 & 127.00 \pm 1.00 & 126.50 \pm 2.12 & 128.00 \pm 1.00 \\ \text { PH } & 171.80 \pm 12.34 & 205.33 \pm 3.51 & 209.17 \pm 13.56 & 209.50 \pm 9.19 & 199.33 \pm 13.01 & 239.00 \pm 41.01 & 229.33 \pm 7.51 \\ \text { HD } & 18.32 \pm 0.69 & 17.80 \pm 1.22 & 18.20 \pm 0.88 & 17.75 \pm 2.05 & 21.47 \pm 1.98 & 18.70 \pm 0.71 & 17.37 \pm 1.20 \\ \text { SY }\left(\mathrm{Kg} / \mathbf{h a}^{-1}\right) & 2917.60 & 3419.00 & 3241.17 & 2608.00 & 2952.33 & 3092.00 & 3326.00 \\ & \pm 180.70 & \pm 309.43 & \pm 149.50 & \pm 254.56 & \pm 361.12 & \pm 459.62 & \pm 32.05 \\ \text { 100SW } & 5.80 \pm 0.59 & 5.65 \pm 0.54 & 6.82 \pm 0.57 & 5.86 \pm 0.23 & 6.36 \pm 0.41 & 5.94 \pm 0.01 & 5.92 \pm 1.00 \\ \text { OC\% } & 37.36 \pm 1.21 & 37.87 \pm 0.35 & 39.25 \pm 0.91 & 38.75 \pm 0.64 & 37.67 \pm 0.42 & 41.55 \pm 0.21 & 38.17 \pm 0.31\end{array}$

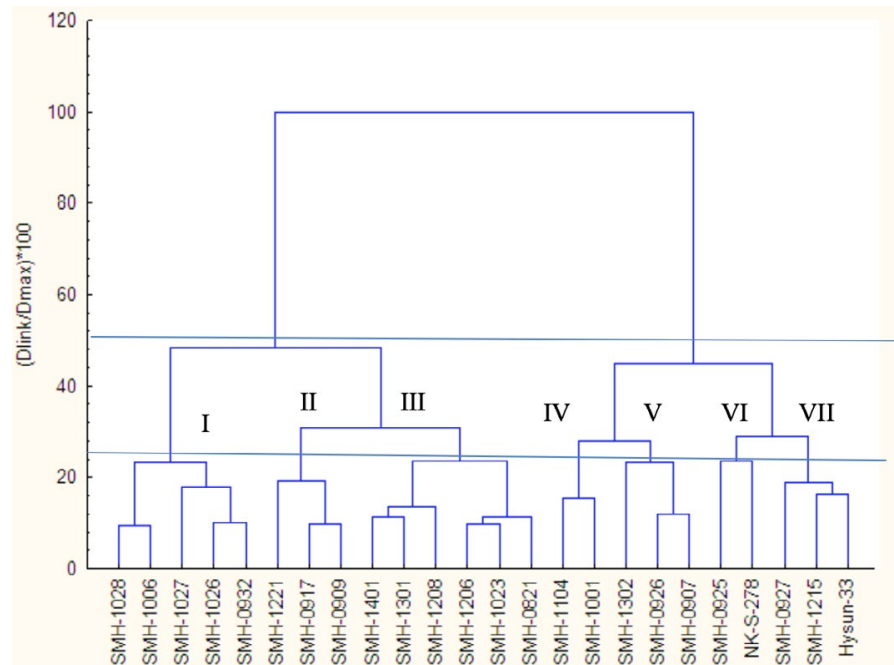

Figure 2: Cluster analysis of eight agronomic traits in twenty four locally developed sunflower hybrids.

hybrids into seven clusters at 25\%. Euclidean distance level (Figure 2). Cluster I comprised of five hybrids and three hybrids were grouped in cluster II, V and VII (each) while cluster IV and VI consisted of two hybrids each. Cluster III was larger and consisted of six hybrids. All the clusters were analyzed for mean and standard deviation (Table 5). Present findings depicted that hybrids in cluster I are short duration and hybrids in cluster $\mathrm{V}$ had maximum head diameter and 100 seed weight. Hybrids in cluster II (SMH-1221, SMH-0917 and SMH-0909) were high in seed yield. SMH-0925 and NK-S-278 in Cluster-VI had higher oil content. Cluster VII (SMH-0927, SMH-1215 and Hysun-33) were high yielding and contain high oil content. Hence, it is concluded that these hybrids can be utilized under diverse set of environment for better outcome. Similar results were reported by Sanju et al. (2018) who found that variation in environment was also responsible for diversity among 116 sunflower restorer lines. In research conducted by Arshad et al. (2007) there were three clusters among which gen- otypes in Cluster-II with higher seed yield, hundred seed weight and oil content were recommended for further testing under diverse environments and selected as desirable genotypes. Similarly, Rehman et al. (2012) reported similar findings in their research conducted on sunflower.

\section{Author's Contribution}

Muhammad Arshad: Overall management of article, Data analysis, Results \& discussion.

Muhammad Ayub Khan: Results \& Discussion, provision of Technical inputs.

Sabeeta Jan: Introduction, sowing of experiment, Data collection.

Sundas Awan: Abstract, Cultural operation, data collection.

Samra Azam: Methodology, Data collection.

Shiguftah Khalid: References, Data collection.

\section{References}

Abbas, S.Q. M.U. Hassan, B. Hussain, T. Rasool and Q. Ali. 2014. Optimization of zinc seed priming treatments for improving the germination and early seedling growth of Oryza sativa. Adv. Life sci. 2(1): 31-37.

Anwar-ul-Haq, A.R., M.A. Butt, A. Saeed and M. Aslam. 2005. Association and path study of some agronomic characters in sunflower $(\mathrm{He}-$ lianthus Annuus L.). J. Agric. Res. 43(4): 323329.

Arshad, M., A. Bakhsh and A. Ghafoor. 2004. Path coefficient analysis in chickpea (Cicer arietinum L.) under rainfed conditions. Pak. J. Bot. 36(1):75-81.

Arshad, M., M.A. Ilyas and M.A. Khan. 2007. Ge- 
netic Divergance and Path coefficient analysis for seed yield traits in sunflower (Helianthus Annuus. L.) Hybrids. Pak. J. Bot. 39(6): 20092015.

Arshad, M., M.A. Khan, S.A. Jadoon and A.S. Muhmand. 2010. Factor Analysis in sunflower (Helianthus Annuus L.) to investigate desirable hybrids. Pak. J. Bot. 42(6): 4393-4402.

Arshad, M., N. Ali and A. Ghafoor. 2006. Character correlation and path coefficient in soybean (Glycine max L.). Pak. J. Bot. 38(1): 121-130.

Bidgoli, A.M., G.A. Akbari, M.J. Mirhadi, E. Zand and S. Soufizadeh. 2006. Path analysis of the relationships between seed yield and some morphological and phenological traits in safflower (Carthamus tinctorius L.). Euphytica 148(3): 261-268. https://doi.org/10.1007/s10681-0059019-x

Chikkadaviah,H., L. Sujatha and C. Nandini. 2002. Correlation and path analysis in sunflower. Helia. 25(37): 109-117. https://doi.org/10.2298/ HEL0237109C

Dagustu, N., 2002. Correlations and path coefficient analysis of seed yield components in sunflower (Helianthus annuus L.). Turk. J. Field Crops. 7(1): 15-19.

Dewey, J.R. and K.H. Lu. 1959. A correlation and path coefficient analysis of components of crested wheat seed production. Agron. J. 51: 515-518. https://doi.org/10.2134/agronj1959. 00021962005100090002x

Economic Survey of Pakistan.2016-17. Ministry of Finance, Economic Advisor's Wing, Islamabad. Farhatullah, F. and I.H. Khalil. 2006. Path analysis of the coefficients of sunflower (Helianthus annuus L.) hybrids. Int. J. Agric. Bio. 8:621-625.

Ghafoor, A. and Z. Ahmad. 2005. Diversity of agronomic traits and total seed protein in Black gram [Vigna mungo (L.) Hepper]. Acta Biologica Cracoviensia, Series Botanica, Poland. 47(2): 69-75.

Habib, H., S.S. Mehdi and M.A. Anjum. 2006. Genetic association and path analysis for seed yield in sunflower (Helianthus annuus L.). Pak. J. Agric. Sci. 43(3-4): 136-139.

Hladni, N., Škorić, D., Kraljević-Balalić, M., Sakač, Z., Jovanović, D., 2006. Combining ability for oil content and its correlations with other yield components in sunflower (Helianthus annuus L.). Helia 29(44): 101-110.

Jockovic, M., S. Jocic, A. Marjanovic-Jeromela, M.
Ciric, P. Canak, V. Miklic and S. Cvejic. 2015. Biomorphological association and path analysis in sunflower (Helianthus annus L.). Helia. 38(63): 189-199.

Kaya, Y., G. Evci, S. Durak, V. Pekcan, and T. Gucer. 2009. Yield components affecting seed yield and their relationships in sunflower (Helianthus annuus L.). Pak. J. Bot. 41(5): 2261-2269.

Khan, A. 2001. Yield performance, heritability and interrelationship in some quantitative traits in sunflower. Helia. 24: 35-40.

Machikowa, T. and C. Saetang. 2008. Correlation and path coefficient analysis on seed yield in sunflower. Suranaree J. Sci. Technol. 15(3): 243248.

Marinkovic, R. 1992. Path-coefficient analysis of some yield components of sunflower (Helianthus annuus L.). Euphytica. 60(3): 201-205.

Mijic, A., I. Liovic, Z. Zdunic, S. Maric, A.M. Jeromela and M. Jankulovska. 2009. Quantitive analysis of oil yield and its components in sunflower (Helianthus annus L). Rom. Agric. Res. 26: 41-46.

Punia, M.S and H.S. Gill. 1994. Correlations and path coefficient analysis for seed yield traits in sunflower (Helianthus annuus L.). Helia. 17(20): 7-12.

Reeve, Y.U. and J.S. Rao. 1981. Path analysis of yield components in black gram. India. J. Agric. Sci. 51: 378-381. Pak. J. Bot. 22(2): 160-167.

Rehman, R., M. Arshad, M.A. Khan, A.S. Mohmand, G. Shabbir and M.K.N. Shah. 2012. Using multivariate analysis for selecting desirable hybrids in sunflower (Helianthus Annuus L.). Pak. J. Bot. 44(5): 1715-1720.

Sanju, K.R. Kamble, S.P. Pole and M.U. Bhikane. 2018. Genetic divergence analysis in sunflower (Helianthus annuus L.) restorer lines. Int. J. Curr. Microbial. Appl. Sci. 6: 742-749

Shankar, V.G., M. Ganesh, A.R.G. Ranganatha and M.H.V. Bhave. 2006. A study on correlation and path analysis of seed yield and yield components in sunflower (Helianthus annuus L.). Agric. Sci. Digest. 26(2): 87-90.

Singh, R.K. and B.D. Chaudhary. 1979. Biometrical methods in quantitative genetic analysis. Kelyani publisher, New Dehli, India. pp. 303.

Škorić, D., R. Marinković, S. Jocić, D. Jovanović and N. Hladni, N. 2002. Dostignuća i dalji pravci $\mathrm{u}$ oplemenjivanju suncokreta i izbor hibrida za setvu u 2002. godini. Zbornik radova Naučnog 
instituta za ratarstvo i povrtarstvo 36: 147-160.

Sneath, P. H. A. and Sokal, R. R. (1973). Numerical Taxonomy. Freeman, San Francisco, CA.

Zia, Z.U., H.A. Sadaqat, M.H.N. Tahir and B.
Sadia. 2013. Correaltion and path coefficient analysis of various triats in sunflower (Helianthus annuus L.). J. Glob. Innov. Agric. Soc. Sci. 1(1): 5-8. 